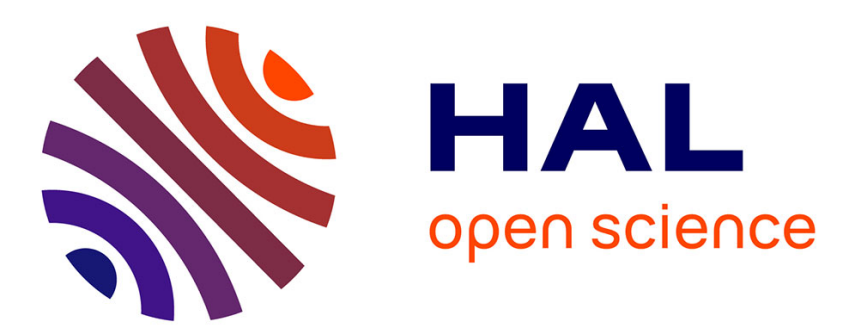

\title{
Effect of pre-heating on the chemical oxidation efficiency: Implications for the PAH availability measurement in contaminated soils
}

Coralie Biache, Catherine Lorgeoux, Sitraka Andriatsihoarana, Stéfan Colombano, Pierre Faure

\section{To cite this version:}

Coralie Biache, Catherine Lorgeoux, Sitraka Andriatsihoarana, Stéfan Colombano, Pierre Faure. Effect of pre-heating on the chemical oxidation efficiency: Implications for the PAH availability measurement in contaminated soils. Journal of Hazardous Materials, 2015, 286, pp.55-63. 10.1016/j.jhazmat.2014.12.041 . hal-01159492

\section{HAL Id: hal-01159492 \\ https://hal.science/hal-01159492}

Submitted on 9 Feb 2018

HAL is a multi-disciplinary open access archive for the deposit and dissemination of scientific research documents, whether they are published or not. The documents may come from teaching and research institutions in France or abroad, or from public or private research centers.
L'archive ouverte pluridisciplinaire HAL, est destinée au dépôt et à la diffusion de documents scientifiques de niveau recherche, publiés ou non, émanant des établissements d'enseignement et de recherche français ou étrangers, des laboratoires publics ou privés. 


\title{
Effect of pre-heating on the chemical oxidation efficiency: Implications for the PAH availability measurement in contaminated soils
}

\author{
Coralie Biache $e^{a, b, *}$, Catherine Lorgeoux ${ }^{c, d}$, Sitraka Andriatsihoarana ${ }^{a, b, c, d, e}$, Stéfan Colombano, \\ Pierre Faure ${ }^{a, b}$
}

\begin{abstract}
aUniversité de Lorraine, LIEC, UMR7360, Vandœuvre-lès-Nancy 54506, France
${ }^{b}$ CNRS, LIEC, UMR7360, Vandœuvre-lès-Nancy 54506, France

'Université de Lorraine, GeoRessources, UMR7359, Vandœuvre-lès-Nancy 54506, France

${ }^{\mathrm{d} C N R S}$, GeoRessources, UMR7359, Vandœuvre-lès-Nancy 54506, France

${ }^{\mathrm{BRGM}}$, Orléans 45060, France

${ }^{*}$ Corresponding author at: LIEC, Boulevard des Aiguillettes, B.P. 70239, 54506 Vandœuvre-lès-Nancy

Cedex, France. Tel.: +33 3836847 40. E-mail address: coralie.biache@yahoo.fr (C. Biache).
\end{abstract}

\section{Highlights}

- $\mathrm{KMnO}_{4}, \mathrm{H}_{2} \mathrm{O}_{2}$ and Fenton-like treatments were applied on PAH-contaminated soils.

- Soils were heated prior the oxidation in order to increase the PAH availability.

- $\mathrm{KMnO}_{4}$ was efficient to degrade PAHs even in samples presenting low PAH-availability.

- $\mathrm{H}_{2} \mathrm{O}_{2}$-based treatments were sensitive to PAH availability

Keywords: Hydrogen peroxide; Potassium permanganate; Fenton-like; Polycyclic aromatic hydrocarbon; Contaminant availability

\begin{abstract}
Three chemical oxidation treatments $\left(\mathrm{KMnO}_{4}, \mathrm{H}_{2} \mathrm{O}_{2}\right.$ and Fenton-like) were applied on three PAHcontaminated soils presenting different properties to determine the potential use of these treatments to evaluate the available PAH fraction. In order to increase the available fraction, a pre-heating (100 ${ }^{\circ} \mathrm{C}$ under $\mathrm{N}_{2}$ for one week) was also applied on the samples prior oxidant addition. PAH and extractable organic matter contents were determined before and after treatment applications. $\mathrm{KMnO}_{4}$ was efficient to degrade PAHs in all the soil samples and the pre-heating slightly improved its efficiency. $\mathrm{H}_{2} \mathrm{O}_{2}$ and Fenton-like treatments presented low efficiency to degrade PAH in the soil presenting poor PAH availability, however, the PAH degradation rates were improved with the pre-heating. Consequently $\mathrm{H}_{2} \mathrm{O}_{2}$-based treatments (including Fenton-like) are highly sensitive to contaminant availability and seem to be valid methods to estimate the available PAH fraction in contaminated soils.
\end{abstract}




\section{Introduction}

The European Environment Agency (EEA) inventoried about 1.5millions of contaminated sites in Europe including 200,000 sites contaminated by polycyclic aromatic compounds (PACs) comprising polycyclic aromatic hydrocarbons (PAHs) [1]. These sites are mostly former coking plant, gas plant and wood treating facilities. In France these sites account for almost $22 \%$ of the inventoried contaminated sites [2]. Due to the PAH recalcitrance and their toxic and carcinogenic properties that place them in the US-EPA pollutant priority list [3], applications of remediation treatments are necessary to rehabilitate these sites. One of the main factors determining the efficiency of these remediation treatments is the contaminant availability [4-6]. Several methods are commonly used to estimate the (bio)available fraction of the contamination. Mild extractions $[7,8]$, cyclodextrine extraction $[9,10]$, Tenax resin extraction [4],passive samplers [11,12], biosensors [13] and microbial incubations [14,15] can be cited. Another method was investigated by Cuypers et al. [16] implying the application of chemical oxidant. Such reagents (e.g., $\mathrm{O}_{3}, \mathrm{KMnO}_{4}, \mathrm{H}_{2} \mathrm{O}_{2}$, persulfate) are commonly used to treat contaminated matrixes and they can be activated by catalyst addition [17-25]. The oxidant action will be different according to the type of reagents and their oxidation potentials. For instance hydrogen peroxide is one of the most common oxidant (oxidation potential c.a. $1.8 \mathrm{~V}$; [26]). Its application, associated with ferrous ions, leads to the formation of $\mathrm{OH}$ radicals which are strong and non-selective oxidant agents (oxidation potential c.a.2.7 V; $[27,28]$ ). Ferrous ions can be introduced in solution and the mixture with $\mathrm{H}_{2} \mathrm{O}_{2}$ is called Fenton's reagent. The catalytic potential of iron mineral can also be used, in this case the process is referred to as Fenton-like oxidation [21]. In aqueous system sodium permanganate and potassium permanganate generate $\mathrm{MnO}_{4}{ }^{-}$ions presenting an oxidation potential of $1.7 \mathrm{~V}$ [17]. Despite this relatively low value, $\mathrm{MnO}_{4}{ }^{-}$are able to break organic compounds containing carbon-carbon double bonds, aldehyde and hydroxyl groups and are therefore, considered as strong oxidant agents [29].

Cuypers et al. [16] validated persulfate oxidation as a method for the bioavailability estimation by comparing the PAH fraction of a contaminated soil chemically degraded to the PAHs biodegraded 
during batch experiment. Therefore chemical oxidants could be used as alternative ways to determine the available fraction of the contamination. Other studies show the strong connection between chemical oxidation efficiency and contaminant availability. Usman et al. [24] studied the Fenton-like treatment applied on former coking plant soils and on their solvent extractable organic matter (EOM) mixed with sand. The treatment efficiency shows major differences with more than $90 \%$ of PAH removal for the EOM/sand mixture whereas oxidation has only negligible effect on the soil PAHs. These results highlight the major constraint of the chemical treatments caused by contamination low availability. The use of solvent extraction to improve PAH availability was explored in another study, where magnetite-activated persulfate treatments were applied on the same soils, with/without a prior solvent extraction [23]. Results demonstrate that the extraction enhances the PAH degradation by magnetite-activated persulfate oxidation by increasing their availability toward the reagents with a modification of the EOM dispersion (including PAHs) on the soil constituents. Although these studies gave new information on chemical oxidation processes and the key role of the contaminant chemoavailability (toward the chemical agent), the field application of solvent extraction to enhance the chemical treatment efficiency seems difficult to implement. Another more practical technique improving the chemo-availability of organic contaminants consists in heating the contaminated matrices at moderate temperatures $\left(60-150^{\circ} \mathrm{C}\right)$ [30].This technique was applied on the same aged coking plant soil and has proven to be capable to enhance the oxidation efficiency (Fenton-like) for PAH contaminated soils presenting low PAH availability [31,32].

The purpose of the present study was to determine if chemical treatment efficiencies can be used as indicator of contaminant availability and to test the effect of pre-heating on the PAH chemical degradation according to (i) the soil properties and (ii) the type of treatments. In order to fulfill these objectives, three PAH contaminated soils, originating from different industrial activities (coking, gasification and wood treatment) and presenting various characteristics (EOM and total organic carbon (TOC) contents, PAH concentrations and distributions) were selected. Several oxidants $\left(\mathrm{H}_{2} \mathrm{O}_{2}\right.$, Fentonlike, $\mathrm{KMnO}_{4}$ ) were applied with/without pre-heating used to enhance the PAH chemo-availability. 


\section{Materials and methods}

\subsection{Soil samples}

The selected soils presented PAH contaminations and originated from the use or transformation of coal or its by-products. Soils were sampled in the former coking plant of Neuves-Maisons (France), in a former gas plant located near Rennes (France) and in an active wood-treating facility located in MidiPyrénées (France).After being collected, the samples were stored at $-18{ }^{\circ} \mathrm{C}$. They were freeze-dried, sieved at $2 \mathrm{~mm}$ and the undersize was crushed at $500 \mu \mathrm{m}$.

\subsection{Thermal treatment}

To modify the PAH availability, fractions of soil samples were placed in $500 \mathrm{~mL}-S c h o t t$ bottles which were hermetically closed under $\mathrm{N}_{2}$, to prevent air-oxidation, and placed in an oven at $100{ }^{\circ} \mathrm{C}$ for one week.

\subsection{Chemical oxidations}

Each soil ( $5 \mathrm{~g}$ ), raw and pre-heated, was placed in $250 \mathrm{~mL}$-Schott bottles. Four reagents were added, (i) $100 \mathrm{~mL}$ of deionized (DI) water, as reference; (ii) $14.5 \mathrm{~mL}$ of $\mathrm{H}_{2} \mathrm{O}_{2}$ (30\% wt) adjusted to $100 \mathrm{~mL}$ with DI water; (iii) Fenton-like reagent with the same procedure as $\mathrm{H}_{2} \mathrm{O}_{2}$ with addition of magnetite (500 mg); (iv) $100 \mathrm{~mL}$ of $\mathrm{KMnO}_{4}$ solution $(16.7 \mathrm{~g} / \mathrm{L})$. The bottles were agitated $(200 \mathrm{rpm}$ ) in the dark for one week. The pre-heated samples were also collected after 1 and $24 \mathrm{~h}$ to follow the reaction kinetics.

\subsection{Organic matter extraction}

OM extractions were carried out on $1.5 \mathrm{~g}$ of each sample with an accelerated solvent extractor (Dionex ASE 350). Copper powder ( $2 \mathrm{~g}$ ) and sodium sulfate ( $2 \mathrm{~g})$ were added to the extraction cells to remove the molecular sulfur and the residual water, respectively. The extractions were performed with dichloromethane (DCM) at $100{ }^{\circ} \mathrm{C}$ and 100 bars for $10 \mathrm{~min}$. After adjusting the volume at $20 \mathrm{~mL}$, aliquots of the solvent extracts $(5 \mathrm{~mL})$ were placed in pre-weighed vials. The EOM content was determined by weighing the vials after solvent evaporation under a gentle $\mathrm{N}_{2}$ flow. 


\subsection{PAH quantification}

Quantification of the 16 listed PAHs (Table S1) was carried out using internal calibration. An internal PAH standard mix ( $20 \mu \mathrm{L}$ at $16 \mu \mathrm{g} / \mathrm{mL}$ ) was added to the EOM ( $80 \mu \mathrm{L})$ before being injected in a gas chromatograph coupled with a mass spectrometer (GC-MS). Analytical conditions and calibration details were reported in the supplementary data file. All results were expressed as a mean value of three experiments and relative standard deviation (RSD) of the three replicates was less than $5 \%$.

\subsection{TOC content measurement}

The TOC content determination was performed with a total carbon analyzer TOC-V CSH (Shimadzu) associated with a solid sample module SSM-5000A (Shimadzu). The catalytic combustion was performed at $900{ }^{\circ} \mathrm{C}$ after carbonate removal with hydrochloric acid (10\% wt).

\subsection{Radiocarbon analysis}

The $\Delta^{14} \mathrm{C}$ activity was measured to determine recent organic carbon proportion in the soil samples [33]. The soils were previously treated with hydrochloric acid $(1 \mathrm{M})$ to remove the mineral carbon (carbonates). Radiocarbon analyses were performed by Poznan radiocarbon laboratory (Poland) and the results were given in percentage of modern carbon (pMC).

\subsection{Soil specific areas}

The specific area of the different soils and the soils previously extracted with DCM were determined in the dry state using conventional step-by-step volumetric adsorption equipment (B.E.T.) to perform complete nitrogen gas adsorption-desorption cycles at $77 \mathrm{~K}$. The samples were degased at $110{ }^{\circ} \mathrm{C}$ under vacuum prior adsorption.

\section{Results}

\subsection{Initial samples}


The soil samples presented various TOC, EOM and PAH contents (Table 1). The TOC varied from 3.3 to $17.2 \%$ for the gas plant and the wood-treating facility soils, respectively. The coking plant soil presented an intermediate value (6.5\%). The EOM contents were of the same range for the coking and gas plant soils ( 10.3 and $11.5 \mathrm{mg} / \mathrm{g}$, respectively) whereas it was about eight times higher in the woodtreating facility soil ( $81.94 \mathrm{mg} / \mathrm{g})$. Similar ranges of PAH content were observed for the coking and gas plant soils (1146 and $1781 \mu \mathrm{g} / \mathrm{g}$, respectively) and the wood-treating facility soil presented much higher value (c.a. $12,000 \mu \mathrm{g} / \mathrm{g}$, Fig. S1).The PAH distribution varied according to the sample origin, the coking plant soil presenting a distribution dominated by 4- and 5-ring PAHs, whereas 2- to 4-ring PAHs dominated the gas plant soil, and pyrene and fluoranthene represented the dominant PAHs in the wood-treating facility soil. These differences were underlined by the low molecular weight over high molecular weight (LMW/HMW) ratio (sum of naphthalene to pyrene concentrations over sum of benz[a]pyrene to benzo[ghi]perylene concentrations; Table 1$)$. This ratio presented a relatively low value for the coking plant soil (0.82) and very high value for the wood-treating facility soil (78) due to high fluoranthene and pyrene concentrations. The soil specific areas varied from 2.1 to $9.8 \mathrm{~m}^{2} / \mathrm{g}$ for the wood-treating facility and the coking plant soils, respectively (Table 2). The gas plant soil showed an intermediate value $\left(4.6 \mathrm{~m}^{2} / \mathrm{g}\right)$. The EOM removal induced an increase in the specific area for all samples and reached 5.5, 9.2 and $12.8 \mathrm{~m}^{2} / \mathrm{g}$ for the wood-treating facility, the gas plant and the coking plant soils, respectively. Consequently, the EOM occupied 62,50 and $23 \%$ of the specific surface, respectively.

\subsection{Effect of the heating pretreatment on the initial samples}

The pre-heating used to enhance the PAH availability induced only a slight decrease in the EOM content (Table 1) of the three soils. It did not cause any modification of the PAH content and distribution (Table 1). 
Table 1: Total organic carbon (TOC), extractable organic matter (EOM), modern carbon percentage (pMC) and PAH contents of the initial and pre-heated soils ( 1 week at $100^{\circ} \mathrm{C}$ under $\mathrm{N}_{2}$ ) (n.d.: not detected).

\begin{tabular}{|c|c|c|c|c|c|c|}
\hline & \multicolumn{2}{|c|}{ Coking plant } & \multicolumn{2}{|c|}{ Gas plant } & \multicolumn{2}{|c|}{ Wood treating facility } \\
\hline & Initial & Preheated & Initial & Preheated & Initial & Preheated \\
\hline TOC (\%) & 6.5 & / & 3.3 & / & 17.2 & 7 \\
\hline $\mathrm{EOM}(\mathrm{mg} / \mathrm{g})$ & 10.30 & 9.42 & 11.50 & 10.21 & 81.94 & 73.10 \\
\hline pMC (\%) & 5.6 & / & 14.7 & / & 21.8 & / \\
\hline $\mathrm{PAH}(\mu \mathrm{g} / \mathrm{g})$ & & & & & & \\
\hline Naphthalene & 35 & 40 & 130 & 110 & 4.8 & 4.9 \\
\hline Acenaphthylene & 24 & 20 & 59 & 18 & 55 & 39 \\
\hline Acenaphthene & 28 & 28 & 28 & 25 & 320 & 280 \\
\hline Fluorene & 20 & 18 & 88 & 82 & 130 & 130 \\
\hline Phenanthrene & 87 & 100 & 290 & 300 & 640 & 670 \\
\hline Anthracene & 28 & 28 & 80 & 72 & 160 & 160 \\
\hline Fluoranthene & 170 & 190 & 310 & 320 & 6100 & 6000 \\
\hline Pyrene & 130 & 150 & 230 & 230 & 4400 & 4300 \\
\hline Benz[a]anthracene & 91 & 110 & 110 & 100 & 53 & 53 \\
\hline Chrysene & 71 & 80 & 81 & 74 & 51 & 51 \\
\hline Benzo[b]fluoranthene & 120 & 140 & 90 & 77 & 26 & 25 \\
\hline Benzo[k]fluoranthene & 53 & 62 & 44 & 43 & 5.8 & 7.2 \\
\hline Benz $[a]$ pyrene & 87 & 84 & 90 & 82 & 16 & 15 \\
\hline Dibenz $[a, h]$ anthracene & 19 & 22 & 13 & 11 & n.d. & n.d. \\
\hline Indeno[1,2,3-cd]pyrene & 92 & 100 & 62 & 56 & n.d. & n.d. \\
\hline Benzo[ghi]perylene & 72 & 85 & 52 & 45 & n.d. & n.d. \\
\hline$\Sigma 16 \mathrm{PAHs}^{\mathrm{a}}$ & 1127 & 1257 & 1757 & 1645 & 11962 & 11700 \\
\hline $\mathrm{LMW}^{\mathrm{H}} \mathrm{HMW}^{\mathrm{b}}$ & 0.9 & 0.9 & 2.3 & 2.4 & 78 & 76 \\
\hline
\end{tabular}

a $\Sigma 16$ PAHs: Sum of the concentrations of the16 PAHs listed by the US-EPA as priority pollutants ${ }^{b}$ LMW/HMW: Sum of low molecular weight PAH concentrations (naphthalene to pyrene) over sum of high molecular weight PAH concentrations (benz[a]anthracene to benzo[ghi]perylene)

\subsection{Effect of the chemical oxidations}

\subsubsection{Potassium permanganate $\left(\mathrm{KMnO}_{4}\right)$}

Compared to the references (one week in water), $\mathrm{KMnO}_{4}$ addition induced a decrease in the EOM contents of the three samples (Fig. 1) which was more important for the gas plant soil compared to the other samples. Heating the samples prior $\mathrm{KMnO}_{4}$ application induced a more important decrease in the EOM contents of the coking and the gas plant soils whereas the pre-heating had minor impact on the wood-treating facility EOM. Overall, $\mathrm{KMnO}_{4}$ induced a decrease in the PAH content (Table 3, Fig. S2). It decreased by half in the coking plant soil. The pre-heating enhanced this diminution which reached more than $70 \%$. The diminution was more important for the gas plant soil $(87 \%)$ than for the other samples and it was also enhanced by the pre-heating (96\%). The steadiness of the LMW/HMW ratio in both cases indicated no preferential degradation of one fraction or the other. For the wood- 
treating facility soil, which showed the highest PAH contents, the pre-heating did not seem to affect the degradation efficiency since the PAH abatement reached $59 \%$ and $62 \%$ for the unheated and the pre-heated samples, respectively. The $\mathrm{LMW} / \mathrm{HMW}$ was affected by $\mathrm{KMnO}_{4}$ due to the diminution of fluoranthene and pyrene concentrations (Table 3), those two compounds being main LMW PAHs; the pre-heating did not affect this ratio any further. The EOM and PAH contents of the pre-heated soils sampled at different times after the treatment application ( $1 \mathrm{~h}, 24 \mathrm{~h}$ and one week) showed that most of the decrease occurred during the first hour following $\mathrm{KMnO}_{4}$ addition and kept going until the end of the experiment (Fig. 2). In the gas plant and wood-treating facility soils the EOM proportion decreased more slowly and in a lesser extent than the PAH proportion whereas the opposite was true for the coking plant soil.

Table 2: Soil and of solvent-extracted soil specific areas ( \pm SD) and the proportion of area occupied by extractable organic matter (EOM).

\begin{tabular}{|c|c|}
\hline Samples & Specific area $\left(\mathrm{m}^{2} / \mathrm{g}\right)$ \\
\hline Coking plant soil & $9.8 \pm 0.2$ \\
\hline Extracted coking plant soil & $12.8 \pm 0.2$ \\
\hline EOM surface ${ }^{a}$ & $23 \%$ \\
\hline Gas plant soil & $4.6 \pm 0.3$ \\
\hline Extracted gas plant soil & $9.2 \pm 0.2$ \\
\hline EOM surface ${ }^{a}$ & $50 \%$ \\
\hline Wood treating facility soil & $2.1 \pm 0.4$ \\
\hline Extracted wood treating facility soil & $5.5 \pm 0.3$ \\
\hline EOM surface ${ }^{a}$ & $62 \%$ \\
\hline
\end{tabular}

a Proportion of the specific area occupied by the EOM calculated by difference in the specific area between the non extracted and the extracted samples

\subsubsection{Hydrogen peroxide $\left(\mathrm{H}_{2} \mathrm{O}_{2}\right)$}

The coking plant soil EOM remained stable after $\mathrm{H}_{2} \mathrm{O}_{2}$ application (Fig. 1) whereas the pre-heating induced a $25 \%$ decrease. The gas plant soil exhibited the highest EOM decrease with $67 \%$ and $87 \%$ for the unheated and the pre-heated samples, respectively. In the wood-treating facility soil $\mathrm{H}_{2} \mathrm{O}_{2}$ caused only a minor decrease in the EOM contents (7\%) which was slightly enhanced by the pre-heating (9\%). The evolution of the PAH content in the coking plant soil showed the same pattern as the EOM (Table 4, Fig. S3). It remained steady after the $\mathrm{H}_{2} \mathrm{O}_{2}$ application and the pre-heating allowed $18 \%$ of $\mathrm{PAH}$ degradation with no discrimination between LMW and HMW PAHs, as attested by the steady LMW/HMW ratio (Table 4). The PAH evolution was also similar to the EOM in the gas plant soil after 
$\mathrm{H}_{2} \mathrm{O}_{2}$ application with $89 \%$ and $92 \%$ of $\mathrm{PAH}$ decrease in the unheated and the pre-heated soil, respectively. For the wood-treating facility soil, the PAH diminution was much higher than the EOM and was about the same range for the unheated and the pre-heated samples $(53 \%$ and $49 \%$, respectively). Most of the PAH and EOM decrease occurred during the first hour following the $\mathrm{H}_{2} \mathrm{O}_{2}$ addition (Fig. 3) in the coking plant and the wood-treating facility pre-heated soils. On the contrary, the decrease in EOM and PAH proportions continued until the end of the experiment for the gas plant soil. As with the $\mathrm{KMnO}_{4}$, the diminution of the PAH proportion was faster and more extended than the decrease in EOM proportions in both gas plant and wood-treating facility soils, unlike the coking plant soil where the decrease in PAH proportion was slower and less extended than the EOM diminution.
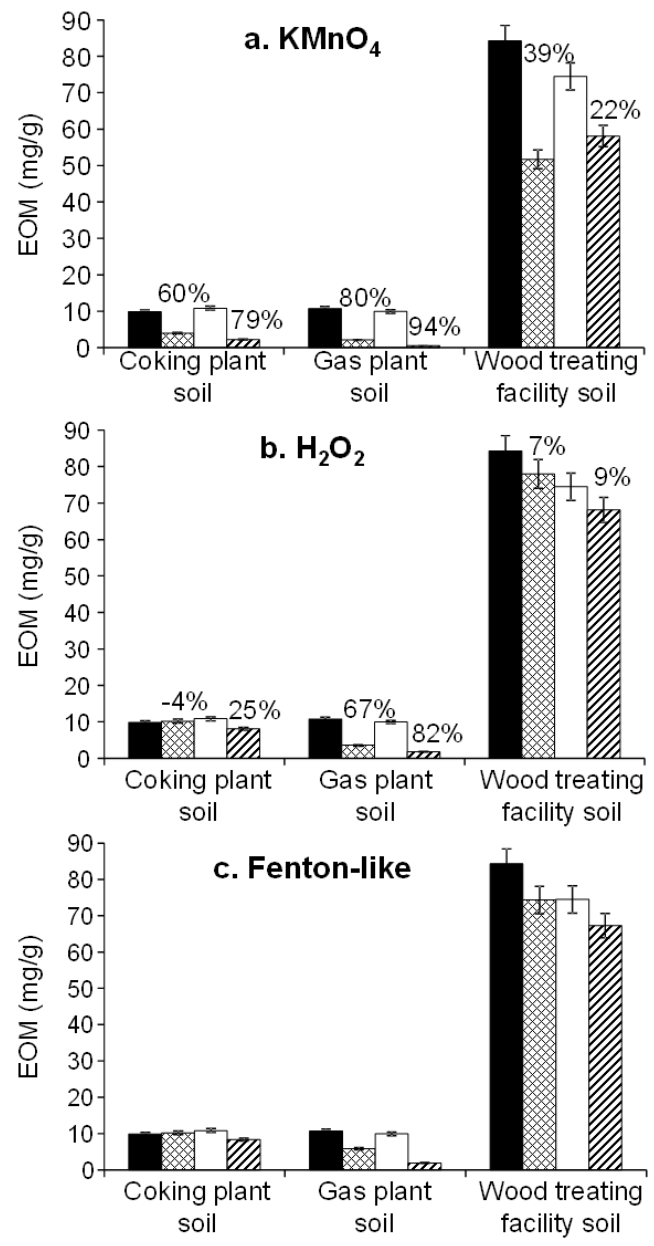

- Reference

$\square$ Pre-heated reference

$\otimes$ Treated(1week) $\square$ Pre-heated and treated (1 week)

Figure 1: Extractable organic matter (EOM) content for the references (one week in water) and samples treated with (a) $\mathrm{KMnO}_{4}$, (b) $\mathrm{H}_{2} \mathrm{O}_{2}$ and (c) Fenton-like (one week), with/without pre-heating ( $\pm \mathrm{SD}$; percentages correspond to the EOM decrease rate after the treatments compared to the reference counterparts) 
Table 3: Soil PAH concentrations in the reference $\left(\mathrm{H}_{2} \mathrm{O}\right.$ for one week) and one week after $\mathrm{KMnO}_{4}$ application, with (PH)/without pre-heating (n.d.: not detected).

\begin{tabular}{|c|c|c|c|c|c|c|c|c|c|c|c|c|}
\hline \multirow[b]{2}{*}{$(\mu \mathrm{g} / \mathrm{g})$} & \multicolumn{4}{|c|}{ Coking plant soil } & \multicolumn{4}{|c|}{ Gas plant soil } & \multicolumn{4}{|c|}{ Wood treating facility } \\
\hline & Reference & $\mathrm{KMnO}_{4}$ & $\begin{array}{c}\mathrm{PH} \\
\text { reference }\end{array}$ & $\begin{array}{c}\mathrm{PH} \\
\mathrm{KMnO}_{4}\end{array}$ & Reference & $\mathrm{KMnO}_{4}$ & $\begin{array}{c}\mathrm{PH} \\
\text { reference }\end{array}$ & $\begin{array}{c}\mathrm{PH} \\
\mathrm{KMnO}_{4}\end{array}$ & Reference & $\mathrm{KMnO}_{4}$ & $\begin{array}{c}\mathrm{PH} \\
\text { reference }\end{array}$ & $\begin{array}{c}\mathrm{PH} \\
\mathrm{KMnO}_{4}\end{array}$ \\
\hline Naphthalene & 24 & 21 & 21 & 17 & 11 & 5.4 & 19 & 5.7 & 4.6 & 6.3 & 3.4 & 5.0 \\
\hline Acenaphthylene & 23 & 7.8 & 17 & 4.0 & 37 & 4.7 & 17 & 1.6 & 58 & 30 & 31 & 28 \\
\hline Acenaphthene & 21 & 9.4 & 22 & 5.4 & 9.8 & n.d. & 11 & n.d. & 110 & n.d. & 46 & 0.8 \\
\hline Fluorene & 15 & 5.5 & 13 & 3.5 & 11 & 0.4 & 50 & 0.7 & 100 & 0.9 & 58 & 4.7 \\
\hline Phenanthrene & 61 & 47 & 85 & 33 & 31 & 25 & 320 & 8.7 & 640 & 390 & 310 & 220 \\
\hline Anthracene & 24 & 10 & 23 & 6.8 & 57 & 7.0 & 69 & 5.0 & 170 & 100 & 150 & 100 \\
\hline Fluoranthene & 150 & 85 & 170 & 59 & 390 & 47 & 330 & 13 & 6300 & 3200 & 6400 & 2900 \\
\hline Pyrene & 120 & 56 & 120 & 34 & 310 & 24 & 240 & 6.2 & 4600 & 1100 & 4400 & 1000 \\
\hline Benz $[a]$ anthracene & 85 & 33 & 91 & 18 & 150 & 11 & 110 & 4.1 & 51 & 35 & 51 & 34 \\
\hline Chrysene & 70 & 34 & 71 & 26 & 99 & 15 & 84 & 3.9 & 51 & 47 & 43 & 50 \\
\hline Benzo[b]fluoranthene & 110 & 59 & 130 & 35 & 100 & 20 & 97 & 4.4 & 27 & 27 & 23 & 29 \\
\hline Benzo[k]fluoranthene & 47 & 28 & 56 & 18 & 64 & 9.2 & 45 & 1.0 & 6.5 & 4.6 & 5.8 & 4.9 \\
\hline Benzo[a]pyrene & 79 & 19 & 72 & 7.4 & 110 & 7.2 & 87 & 3.4 & 16 & n.d. & 16 & 17 \\
\hline Dibenz $[a, h]$ anthracene & 18 & 8.5 & 21 & 4.6 & 16 & 2.6 & 13 & 0.6 & n.d. & n.d. & n.d. & n.d. \\
\hline Indeno[1,2,3-cd]pyrene & 94 & 39 & 98 & 24 & 79 & 11 & 65 & 2.1 & n.d. & n.d. & n.d. & n.d. \\
\hline Benzo[ghi]perylene & 71 & 30 & 74 & 20 & 68 & 8.9 & 56 & 1.7 & n.d. & n.d. & n.d. & n.d. \\
\hline$\Sigma 16 \mathrm{PAHs}^{\mathrm{a}}$ & 1012 & 492 & 1084 & 316 & 1543 & 198 & 1613 & 62 & 12134 & 4940 & 11537 & 4393 \\
\hline $\mathrm{LMW} / \mathrm{HMW}^{\mathrm{b}}$ & 0.8 & 1.0 & 0.8 & 1.1 & 1.2 & 1.3 & 1.9 & 1.9 & 79 & 42 & 82 & 32 \\
\hline PAH decrease (\%) & & 51 & & 71 & & 87 & & 96 & & 59 & & 62 \\
\hline
\end{tabular}

a $\Sigma 16$ PAHs: Sum of the concentrations of the16 PAHs listed by the US-EPA as priority pollutants

${ }^{b}$ LMW/HMW: Sum of low molecular weight PAH concentrations (naphthalene to pyrene) over sum of high molecular weight PAH concentrations (benz[a]anthracene to benzo[ghi]perylene) 
Table 4: Soil PAH concentrations in the reference $\left(\mathrm{H}_{2} \mathrm{O}\right.$ for one week) and one week after $\mathrm{H}_{2} \mathrm{O}_{2}$ application, with (PH)/without pre-heating (n.d.: not detected).

\begin{tabular}{|c|c|c|c|c|c|c|c|c|c|c|c|c|}
\hline \multirow[b]{2}{*}{$(\mu \mathrm{g} / \mathrm{g})$} & \multicolumn{4}{|c|}{ Coking plant soil } & \multicolumn{4}{|c|}{ Gas plant soil } & \multicolumn{4}{|c|}{ Wood treating facility } \\
\hline & Reference & $\mathrm{H}_{2} \mathrm{O}_{2}$ & $\begin{array}{c}\mathrm{PH} \\
\text { reference }\end{array}$ & $\begin{array}{c}\mathrm{PH} \\
\mathrm{H}_{2} \mathrm{O}_{2}\end{array}$ & Reference & $\mathrm{H}_{2} \mathrm{O}_{2}$ & $\begin{array}{c}\mathrm{PH} \\
\text { reference }\end{array}$ & $\begin{array}{c}\mathrm{PH} \\
\mathrm{H}_{2} \mathrm{O}_{2}\end{array}$ & Reference & $\mathrm{H}_{2} \mathrm{O}_{2}$ & $\begin{array}{c}\mathrm{PH} \\
\text { reference }\end{array}$ & $\begin{array}{c}\mathrm{PH} \\
\mathrm{H}_{2} \mathrm{O}_{2}\end{array}$ \\
\hline Naphthalene & 24 & 31 & 21 & 21 & 11 & 2.4 & 19 & 7.3 & 4.6 & 4.7 & 3.4 & 3.4 \\
\hline Acenaphthylene & 23 & 26 & 17 & 15 & 37 & 8.0 & 17 & 3.3 & 58 & 46 & 31 & 29 \\
\hline Acenaphthene & 21 & 24 & 22 & 15 & 9.8 & n.d. & 11 & 0.5 & 110 & 21 & 46 & 20 \\
\hline Fluorene & 15 & 19 & 13 & 11 & 11 & 2.1 & 50 & 4.2 & 100 & 39 & 58 & 30 \\
\hline Phenanthrene & 61 & 87 & 85 & 80 & 31 & 19 & 320 & 24 & 640 & 550 & 310 & 520 \\
\hline Anthracene & 24 & 25 & 23 & 18 & 57 & 5.8 & 69 & 7.1 & 170 & 120 & 150 & 100 \\
\hline Fluoranthene & 150 & 160 & 170 & 140 & 390 & 32 & 330 & 21 & 6300 & 3000 & 6400 & 3100 \\
\hline Pyrene & 120 & 140 & 120 & 110 & 310 & 19 & 240 & 15 & 4600 & 1800 & 4400 & 1900 \\
\hline Benz $[a]$ anthracene & 85 & 89 & 91 & 69 & 150 & 13 & 110 & 7.6 & 51 & 46 & 51 & 42 \\
\hline Chrysene & 70 & 70 & 71 & 59 & 99 & 11 & 84 & 6.2 & 51 & 46 & 43 & 45 \\
\hline Benzo[b]fluoranthene & 110 & 86 & 130 & 98 & 100 & 16 & 97 & 7.9 & 27 & 24 & 23 & 26 \\
\hline Benzo[k]fluoranthene & 47 & 54 & 56 & 46 & 64 & 6.6 & 45 & 3.0 & 6.5 & 4.7 & 5.8 & 5.9 \\
\hline Benzo[a]pyrene & 79 & 78 & 72 & 55 & 110 & 11 & 87 & 6.1 & 16 & 14 & 16 & 14 \\
\hline Dibenz $[a, h]$ anthracene & 18 & 19 & 21 & 16 & 16 & 2.3 & 13 & 1.1 & n.d. & n.d. & n.d. & n.d. \\
\hline Indeno[1,2,3-cd]pyrene & 94 & 86 & 98 & 73 & 79 & 12 & 65 & 5.1 & n.d. & n.d. & n.d. & n.d. \\
\hline Benzo[ghi]perylene & 71 & 73 & 74 & 59 & 68 & 9.8 & 56 & 4.3 & n.d. & n.d. & n.d. & n.d. \\
\hline$\Sigma 16 \mathrm{PAHs}^{\mathrm{a}}$ & 1012 & 1067 & 1084 & 885 & 1543 & 170 & 1613 & 124 & 12134 & 5715 & 11537 & 5835 \\
\hline $\mathrm{LMW} / \mathrm{HMW}^{\mathrm{b}}$ & 0.8 & 0.9 & 0.8 & 0.8 & 1.2 & 1.1 & 1.9 & 2.0 & 79 & 41 & 82 & 43 \\
\hline PAH decrease (\%) & & 0 & & 18 & & 89 & & 92 & & 53 & & 49 \\
\hline
\end{tabular}

a 16 PAHs: Sum of the concentrations of the16 PAHs listed by the US-EPA as priority pollutants

${ }^{b}$ LMW/HMW: Sum of low molecular weight PAH concentrations (naphthalene to pyrene) over sum of high molecular weight PAH concentrations (benz[ $a$ ]anthracene to benzo[ghi]pérylène) 
Table 5: Soil PAH concentrations in the reference $\left(\mathrm{H}_{2} \mathrm{O}\right.$ for one week) and one week after Fenton-like treatment, with (PH)/without pre-heating (n.d.: not detected).

\begin{tabular}{|c|c|c|c|c|c|c|c|c|c|c|c|c|}
\hline \multirow[b]{2}{*}{ ( $\mu \mathrm{g} / \mathrm{g})$} & \multicolumn{4}{|c|}{ Coking plant soil } & \multicolumn{4}{|c|}{ Gas plant soil } & \multicolumn{4}{|c|}{ Wood treating facility } \\
\hline & Reference & $\begin{array}{l}\text { Fenton- } \\
\text { like }\end{array}$ & $\begin{array}{c}\mathrm{PH} \\
\text { reference }\end{array}$ & $\begin{array}{c}\mathrm{PH} \\
\text { Fenton- } \\
\text { like } \\
\end{array}$ & Reference & $\begin{array}{l}\text { Fenton- } \\
\text { like }\end{array}$ & $\begin{array}{c}\mathrm{PH} \\
\text { reference }\end{array}$ & $\begin{array}{c}\mathrm{PH} \\
\text { Fenton- } \\
\text { like } \\
\end{array}$ & Reference & $\begin{array}{l}\text { Fenton- } \\
\text { like }\end{array}$ & $\begin{array}{c}\mathrm{PH} \\
\text { reference }\end{array}$ & $\begin{array}{c}\mathrm{PH} \\
\text { Fenton- } \\
\text { like }\end{array}$ \\
\hline Naphthalene & 24 & 28 & 21 & 25 & 11 & 5.9 & 19 & 7.4 & 4.6 & 5.3 & 3.4 & 4.3 \\
\hline Acenaphthylene & 23 & 27 & 17 & 16 & 37 & 16 & 17 & 3.6 & 58 & 48 & 31 & 31 \\
\hline Acenaphthene & 21 & 25 & 22 & 18 & 9.8 & 1.5 & 11 & 0.8 & 110 & 36 & 46 & 30 \\
\hline Fluorene & 15 & 19 & 13 & 11 & 11 & 5.0 & 50 & 4.1 & 100 & 53 & 58 & 38 \\
\hline Phenanthrene & 61 & 86 & 85 & 77 & 31 & 45 & 320 & 24 & 640 & 600 & 310 & 550 \\
\hline Anthracene & 24 & 27 & 23 & 19 & 57 & 10 & 69 & 7.0 & 170 & 120 & 150 & 100 \\
\hline Fluoranthene & 150 & 160 & 170 & 140 & 390 & 65 & 330 & 21 & 6300 & 3200 & 6400 & 3000 \\
\hline Pyrene & 120 & 130 & 120 & 110 & 310 & 38 & 240 & 15 & 4600 & 2100 & 4400 & 1900 \\
\hline Benz[a]anthracene & 85 & 86 & 91 & 71 & 150 & 24 & 110 & 7.3 & 51 & 45 & 51 & 44 \\
\hline Chrysene & 70 & 69 & 71 & 64 & 99 & 23 & 84 & 6.1 & 51 & 46 & 43 & 48 \\
\hline Benzo[b]fluoranthene & 110 & 100 & 130 & 91 & 100 & 30 & 97 & 7.7 & 27 & 27 & 23 & 25 \\
\hline Benzo[k]fluoranthene & 47 & 51 & 56 & 41 & 64 & 13 & 45 & 2.8 & 6.5 & 5.2 & 5.8 & 5.6 \\
\hline Benzo[a]pyrene & 79 & 78 & 72 & 48 & 110 & 18 & 87 & 6.2 & 16 & 16 & 16 & 15 \\
\hline Dibenz $[a, h]$ anthracene & 18 & 18 & 21 & 15 & 16 & 4.1 & 13 & 1.1 & n.d. & n.d. & n.d. & n.d. \\
\hline Indeno[1,2,3-cd]pyrene & 94 & 82 & 98 & 69 & 79 & 21 & 65 & 5.1 & n.d. & n.d. & n.d. & n.d. \\
\hline Benzo[ghi]perylene & 71 & 67 & 74 & 54 & 68 & 17 & 56 & 4.2 & n.d. & n.d. & n.d. & n.d. \\
\hline$\Sigma 16 \mathrm{PAHs}^{\mathrm{a}}$ & 1012 & 1053 & 1084 & 869 & 1543 & 337 & 1613 & 123 & 12134 & 6302 & 11537 & 5791 \\
\hline $\mathrm{LMW} / \mathrm{HMW}^{\mathrm{b}}$ & 0.8 & 0.9 & 0.8 & 0.9 & 1.2 & 1.2 & 1.9 & 2.0 & 79 & 44 & 82 & 41 \\
\hline PAH decrease (\%) & & 0 & & 20 & & 78 & & 92 & & 48 & & 50 \\
\hline
\end{tabular}

a 16 PAHs: Sum of the concentrations of the16 PAHs listed by the US-EPA as priority pollutants

${ }^{b}$ LMW/HMW: Sum of low molecular weight PAH concentrations (naphthalene to pyrene) over sum of high molecular weight PAH concentrations (benz[ $a$ ]anthracene to

benzo[ghi]perylene 


\subsubsection{Fenton-like $\left(\mathrm{H}_{2} \mathrm{O}_{2}+\right.$ magnetite $)$}

The EOM evolution after the Fenton-like treatment was very similar to the one observed with $\mathrm{H}_{2} \mathrm{O}_{2}$

(Fig. 1). The coking plant soil EOM content did not decrease except when the sample was pre-heated. Overall, the EOM diminution was always higher when the soils were pre-heated. The gas plant soil was the most affected by the Fenton-like treatment ( $<80 \%$ of EOM decrease). The evolution of the PAH content and distribution was also similar to the one observed after $\mathrm{H}_{2} \mathrm{O}_{2}$ addition (Table 5, Fig.S4). No decrease in PAH content was observed for the coking plant soil, unless the sample was pre-heated (20\% decrease). The unheated and pre-heated gas plant soils showed the highest degradation rates (78\% and $92 \%$, respectively). The PAH degradation rates reached $49 \%$ and $50 \%$, for the unheated and pre-heated wood-treating facility soils, respectively. A decrease in the LMW/HMW ratio of this sample indicated a preferential degradation of LMW compounds (i.e. pyrene and fluoranthene; Table 5). The evolution of EOM and PAH proportions during the Fenton-like treatment of the pre-heated soils were similar to those observed during $\mathrm{H}_{2} \mathrm{O}_{2}$ treatment (Fig. 4). For the coking and gas plant soils, most of the degradation occurred during the first hour following the reagent addition. For the gas plant soil, the proportion of remaining PAHs was lower than the EOM proportion whereas, for the coking plant soil, both were about the same range. The gas plant soil, who showed the highest EOM and PAH degradation rates, exhibited a more important and faster PAH decrease compared to EOM, and the diminution of the EOM and PAH contents kept occurring until the end of the experiment (Fig. 4).

\section{Discussion}

\subsection{Chemical oxidation treatment and evaluation of PAH availability}

\subsubsection{Differences in contamination distribution}

As mentioned previously, three soils presenting various properties (EOM and PAH contents and distributions) were selected because they represented various sites highly impacted by PAH contamination. The coking and gas plant soils presented similar values for the PAH and EOM contents but different PAH distributions, the PAH coking plant soil being dominated by higher molecular weight 
compounds than the gas plant soil. These disparities could be an indication of different soil histories. First, the composition of the original contamination could be responsible for the difference in PAH distribution. Second, the presence of higher molecular weight PAHs in the coking plant soil than in the gas plant soil may be explained by a more advanced level of weathering. Indeed, due to differences in their physicochemical properties, LMW compounds are known to be preferentially affected by evaporation, water-washing and biodegradation com-pared to HMW PAHs [34-36]. The difference in LMW/HMW PAH ratios between the coking and the gas plant soils ( 0.9 and 2.3 , respectively) support this hypothesis. The contamination of the wood-treating facility soil was much higher than for the other soils as the PAH contents were 7 and 10 higher than in the gas and the coking plant soils, respectively. This contamination can be considered as fresh since the wood-treating site is still on activity.

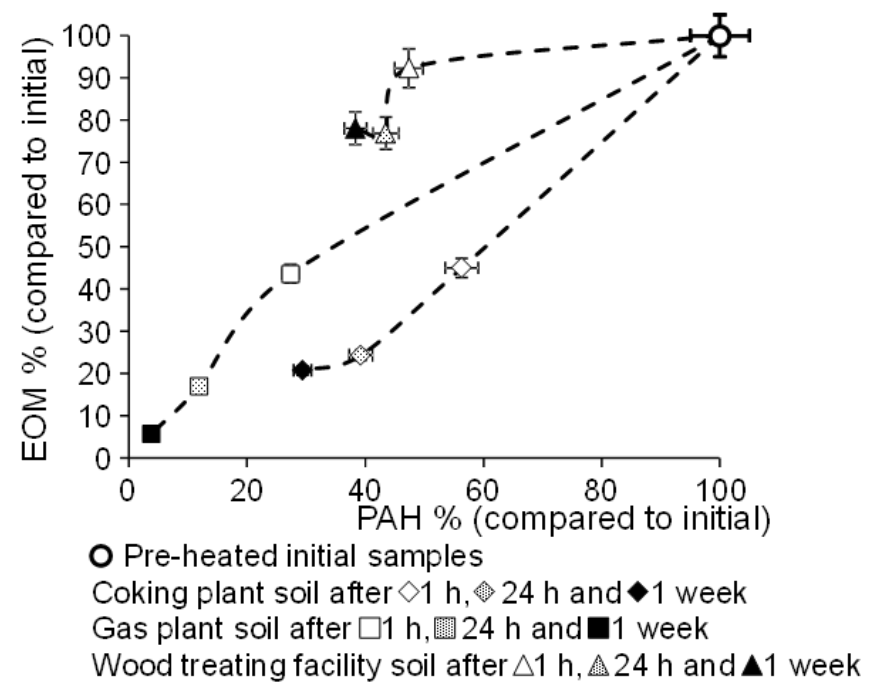

Figure 2: Extractable organic matter (EOM) and PAH proportions related to the initial samples 1, $24 \mathrm{~h}$ and one week after $\mathrm{KMnO}_{4}$ addition in the pre-heated soils ( \pm SD)

\subsubsection{Responses to H2O2and Fenton-like treatments}

Due to the higher oxidation potential of $\mathrm{OH}$ compared to $\mathrm{H}_{2} \mathrm{O}_{2}(2.7 \mathrm{~V}$ and $1.8 \mathrm{~V}$, respectively), the Fenton-like treatment was expected to induce higher degradation rate than the $\mathrm{H}_{2} \mathrm{O}_{2}$. However, the soil responses to both treatments were very similar. Several studies aiming to compare the efficiency 
of $\mathrm{H}_{2} \mathrm{O}$ and Fenton or Fenton-like treatments to degrade PAHs $[18,37]$ point out similar observation i.e. ferrous iron addition has no significant impact on the $\mathrm{PAH}$ degradation with $\mathrm{H}_{2} \mathrm{O}_{2}$. In addition to $\mathrm{H}_{2} \mathrm{O}_{2}$, magnetite was used in the Fenton-like treatment as a catalyst to generate the radicals involved in the oxidation reaction and to increase the reaction kinetic $[17,20,38]$. It is known that other minerals occurring naturally in soil (e.g., magnetite, hematite, goethite, and ferrihydrite) are able to catalyze radical formation [39] and therefore initiate Fenton-like reactions. Indeed Petigara et al. [40] studied $\mathrm{O}_{2}$ and $\mathrm{OH}$ production after $\mathrm{H}_{2} \mathrm{O}_{2}$ application in soils and suggest that organic constituent oxidation with $\mathrm{H}_{2} \mathrm{O}_{2}$ in soils primarily involves $\mathrm{OH}$ reaction rather than peroxidic reactions. Indigenous iron oxides or other metal oxides could participate to initiate Fenton-like reaction in the studied soils explaining why the $\mathrm{H}_{2} \mathrm{O}_{2}$ alone was as efficient as the Fenton-like treatment to degrade EOM and PAHs.

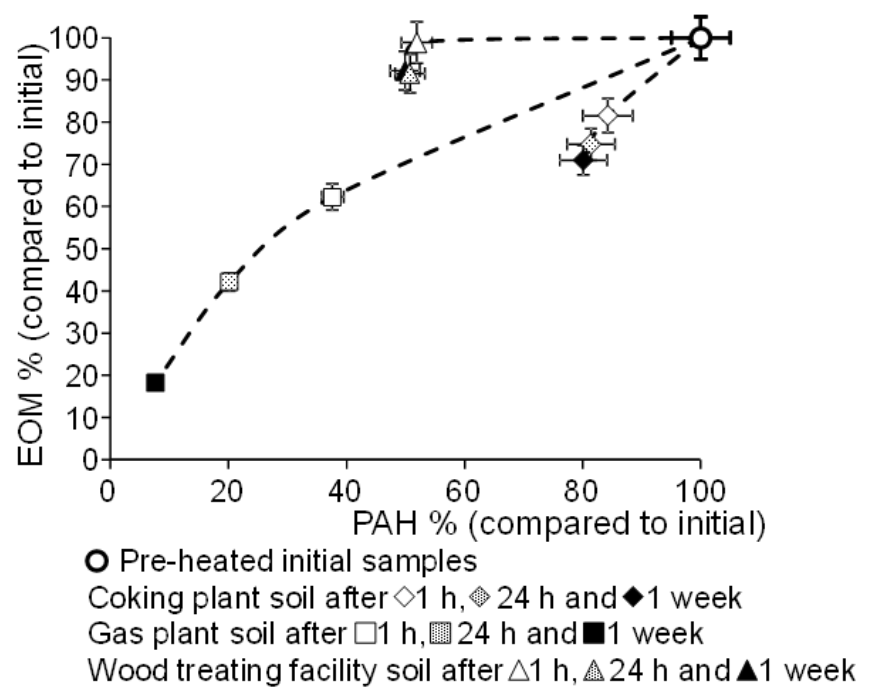

Figure 3: Extractable organic matter (EOM) and PAH proportions related to the initial samples 1, $24 \mathrm{~h}$ and one week after $\mathrm{H} 2 \mathrm{O} 2$ application in the pre-heated soils $( \pm \mathrm{SD}$ )

Both $\mathrm{H}_{2} \mathrm{O}_{2}$ and Fenton-like treatments were very efficient to decrease the PAH concentrations in the gas plant soil but showed less efficiency for the other samples, especially for the coking plant soil. One explanation could be differences in soil structure and contamination repartition. Indeed, the coking plant soil presented higher specific area than the gas plant and the wood-treating facility soils. However, the EOM containing the contamination occupied $23 \%$ of this area which is lower than the 
gas plant soil (50\%). These proportions give indications on the contaminant repartition in soils, impacting the contaminant accessibility toward the oxidant. The higher the surface occupied by the contamination, the higher the surface contact between the oxidant and the contaminant and the higher the probability for the oxidant to react with it. These differences can then explain the higher treatment efficiency for the gas plant soil than for the coking plant soil and be directly related to the contamination (chemo)availability. The poor PAH availability in the coking plant soil was underlined in several studies $[23,24,41-43]$. It has been shown that Fenton treatment efficiency is correlated to the matrix characteristics but also to the PAH availability, in regard to the age and level of contamination $[37,44]$. Indeed, artificially spiked PAHs are more easily oxidized than PAHs from historically contaminated sites [24] due to increasing sorption strength and binding over time [45]. The difference in degradation rate during Fenton-like and $\mathrm{H}_{2} \mathrm{O}_{2}$ treatments between the coking and the gas plant soils was likely due to a decrease in extractability and availability of contaminants with increasing sequestration into the soil during aging.

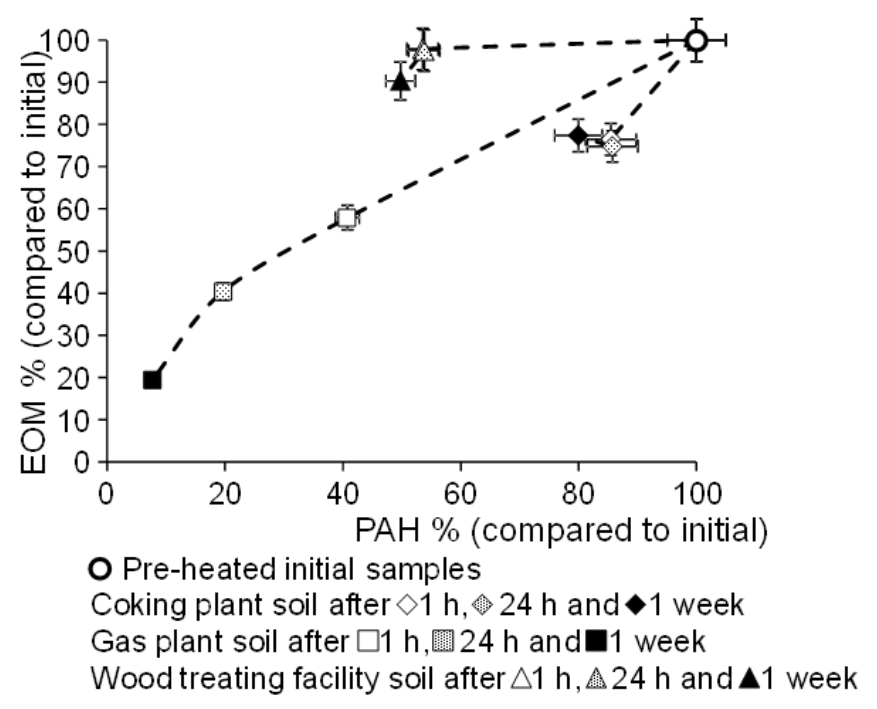

Figure 4: Extractable organic matter (EOM) and PAH proportions related to the initial samples 1, $24 \mathrm{~h}$ and one week after Fenton-like treatment of the pre-heated soils ( \pm SD)

The wood-treating facility soil showed about $50 \%$ of PAH degradation after $\mathrm{H}_{2} \mathrm{O}_{2}$ and Fenton-like oxidations. However, in this case the treatment efficiency was not related to PAH availability since the 
contamination was fresh and biodegradation experiments were proven to effectively reduce PAH concentration of about 96\% [46]. The PAH concentrations in the wood-treating soil being much higher than in the other soils, it seems than the PAH degradation limitation was rather related to the oxidant dose. Indeed, from calculations based on Lemaire et al. [47] the $\mathrm{H}_{2} \mathrm{O}_{2}$ amount added to the woodtreating facility soil corresponded to 11.73 times the stoichiometric oxidant demand (SOD) based only on the PAH concentrations. This value did not take into account the presence and concentrations of other organic compounds that could possibly react with the oxidant. This value was much higher for the other soil samples (158 and 249 for the gas and coking plant soils, respectively) due to lower PAH contents and same oxidant doses.

The PAH and EOM decrease rates in the coking plant soil after $\mathrm{H}_{2} \mathrm{O}_{2}$ and Fenton-like treatments were similar whereas the PAH decrease rates were much higher than the diminution of the EOM proportion in the gas plant and wood-treating facility soils. These observations underlined a selectivity in compound degradation after $\mathrm{H}_{2} \mathrm{O}_{2}$ and Fenton-like treatments in the latter soils. The published results concerning the influence of $\mathrm{OM}$ on $\mathrm{H}_{2} \mathrm{O}_{2}$ and Fenton-like treatment efficiency are opposing. Overall, the OM content is negatively correlated with the treatment efficiency to degrade PAHs due to a competition between PAHs and other organics [18,20,40]. However, Bogan and Trbovic [48] studied the effect of Fenton oxidation on soils spiked with coal tar and presenting various OM and TOC contents. They show that the oxidation efficiency for PAH removal was limited for soils presenting low OM content $(\mathrm{TOC}<5 \%)$ but PAH degradation was much higher in soils rich in OM. The type of OM seems to be a more relevant factor than its content to explain these contradictions [48]. The coking plant soil presented a much lower pMC (Table 1) than the other samples and consequently a higher proportion of fossil carbon [33] i.e. that underwent diagenesis process. Bogan and Trbovic [48] underlined that contamination associated with OM exposed to diagenesis alteration is more refractory than contamination associated with recent OM. The fact that the gas plant and the wood-treating facility soils presented higher PMC than the coking plant soil, and consequently more recent $\mathrm{OM}$, could then explain the selectivity in PAH degradation observed for the former soils. 


\subsubsection{Response to the $\mathrm{KMnO}_{4}$ treatment}

Unlike $\mathrm{H}_{2} \mathrm{O}_{2}$ and Fenton-like, the $\mathrm{KMnO}_{4}$ treatment was very efficient to decrease the PAH concentrations in both gas and coking plant soils. As previously underlined, both soils presented very similar EOM and PAH contents but differences in PAH availability explaining the disparities in the $\mathrm{H}_{2} \mathrm{O}_{2}$ treatment efficiency. However, this parameter did not affect the $\mathrm{KMnO}_{4}$ treatment efficiency in removing PAHs. A previous study [47] has already underlined the high efficiency of $\mathrm{KMnO}_{4}$ to degrade PAHs in aged contaminated soils. When comparing PAH and EOM degradation rates after the $\mathrm{KMnO}_{4}$ treatment, it appeared that the degradation rates were about the same for the coking and the gas plant soils whereas the proportion of degraded PAHs was much higher than the degraded EOM in the wood-treating facility soil, showing a selectivity of the oxidant for the contamination.

\subsection{Effect of the pre-heating on the treatment efficiency}

\subsubsection{Dose limitation}

According to the soil specificities and whatever the chemical treatment applied, two different behaviors in response to the pre-heating can be distinguished. The pre-heating induced an increase in the PAH and EOM abatements for the coking and gas plant soils whereas the effect of the pre-heating was very limited for the wood-treating facility soil. As previously mentioned, the treatment efficiency for this sample was related to dose limitation rather than accessibility constrain (cf. 4.1.2). The preheating did not induce any improvement in the treatment efficiency since the oxidant doses were too low to degrade all the accessible fraction of the contamination. This dose constrain was also visible on the PAH and EOM degradation kinetics as most of the decrease occurred during the first hour following the treatment application on the wood-treating facility soil, whatever the chemical oxidant used.

4.2.2. $\mathrm{H}_{2} \mathrm{O}_{2}$ and Fenton-like treatments: influence of the chemo-availability

For the coking and gas plant soils, differences in the $\mathrm{H}_{2} \mathrm{O}_{2}$ and Fenton-like treatment efficiency were already pointed out. The pre-heating treatment had a marked effect for both soils with an increase in PAH and EOM removal. Differences between these soils can be observed on the degradation kinetics, 
PAHs and EOM being degraded until the end of the experiment (one week) for the gas plant soil whereas most of the degradation occurred during the first hour following the treatment application for the coking plant soil. For the latter, the limited accessibility of the contamination for the $\mathrm{H}_{2} \mathrm{O}_{2}$-based treatment was already underlined $[37,44]$ since the PAH availability was extremely low. The preheating allowed degrading about $20 \%$ of PAHs with $\mathrm{H}_{2} \mathrm{O}_{2}$ and Fenton-like treatments whereas no degradation was observed without it. The pre-heating induced a remobilization of the contamination, likely through a change in the PAH sorption sites. However, even if improved, the availability remained limited. For the gas plant soil there was much less limitation in the PAH availability however, the preheating also improved the degradation.

\subsection{3. $\mathrm{KMnO}_{4}$ treatment}

For all the soils, $\mathrm{KMnO}_{4}$ showed the highest efficiency compared to the other treatments. As shown by the degradation kinetics and contrary to the other treatments, the PAH degradation in the coking plant soil continued until the end of the experiment. As under-lined by Lemaire et al. [47], $\mathrm{MnO}_{4}^{-}$tend to persist in the soil after the treatment application explaining the better efficiency and the longer action duration. The pre-heating also induced better treatment efficiencies even if they seemed less constrained by the PAH availability, as shown by the high degradation rate in the coking plant soil.

\section{Conclusion}

In this study, several oxidation treatments were investigated as way to determine PAH availability in contaminated soils presenting various specificities. A pre-heating was applied to the soils, prior chemical oxidations, to improve the $\mathrm{PAH}$ availability. $\mathrm{H}_{2} \mathrm{O}_{2}$-based treatment (including Fenton-like) efficiency happened to be more sensitive to the PAH accessibility and availability. Therefore $\mathrm{H}_{2} \mathrm{O}_{2}$ and Fenton-like treatments seemed to be valid methods to estimate the $\mathrm{PAH}$ availability, unlike the $\mathrm{KMnO}_{4}$ treatment which was very efficient to degrade PAHs even in samples presenting low contamination availability. 
The pre-heating has proven to be efficient to increase the contamination availability as the treatment efficiencies were enhanced by heating the sample at $100{ }^{\circ} \mathrm{C}$ for one week under $\mathrm{N}_{2}$ prior the oxidant application.

In this study, only the listed PAHs were taken into account, however, it is known that chemical oxidation leads to the formation of oxygenated species $[22,28]$ presenting the same toxic and carcinogenic properties than parent-PAHs [49] but higher solubility, hence an increased mobility, due to the presence of oxygenated moieties $[50,51]$. Since these treatments are commonly used to remediate contaminated matrixes, this statement underlines the importance of dealing with this aspect inherent to the application of chemical oxidation treatments. This question is currently investigated and will be addressed as another part of this project.

\section{Acknowledgements}

We thank the GISFI (French Scientific Interest Group - Industrial Wasteland, www.gisfi.prd.fr). We also thank Angelina Razafitianamaharavo for the soil specific area determination. This article is a part of the SNOWMAN III European project and is financially supported by the French Environment and Energy Management Agency (ADEME).

\section{References}

[1] E.E.A, http://www.eea.europa.eu/data-and-maps/figures/overview-of-contaminants-affectingsoil-and-groundwater-in-europe, 2012.

[2] BASOL, http://basol.developpement-durable.gouv.fr/home.htm, 2014.

[3] L.H. Keith, W.A. Telliard, Priority pollutants I - a perspective view, Environ. Sci. Technol. 13 (1979) 416-423. 
[4] S. Ahn, D. Werner, R.G. Luthy, Physicochemical characterization of coke-plant soil for the assessment of polycyclic aromatic hydrocarbon availability and the feasibility of phytoremediation, Environ. Toxicol. Chem. 24 (2005) 2185-2195.

[5] V. Leonardi, V. Sasek, M. Petruccioli, A. D’Annibale, P. Erbanová, T. Cajthaml, Bioavailability modification and fungal biodegradation of PAHs in aged industrial soils, Int. Biodeter. Biodegr. 60 (2007) 165-170.

[6] C. Löser, H. Seidel, P. Hoffmann, A. Zehnsdorf, Bioavailability of hydrocarbons during microbial remediation of a sandy soil, Appl. Microbiol. Biotechnol. 51 (1999) 105-111.

[7] U. Ghosh, J.R. Zimmerman, R.G. Luthy, $\mathrm{PCB}$ and $\mathrm{PAH}$ speciation among particle types in contaminated harbor sediments and effects on PAH bioavailability, Environ. Sci. Technol. 37 (2003) $2209-2217$.

[8] H.H. Liste, M. Alexander, Butanol extraction to predict bioavailability of PAHs in soil, Chemosphere 46 (2002) 1011-1017.

[9] E. Puglisi, C.J. Patterson, G.I. Paton, Non-exhaustive extraction techniques (NEETs) for bioavailability assessment of organic hydrophobic compounds in soils, Agronomie 23 (2003) 755-756.

[10] B.J. Reid, J.D. Stokes, K.C. Jones, K.T. Semple, Nonexhaustive cyclodextrin-based extraction technique for the evaluation of PAH bioavailability, Environ. Sci. Technol. 34 (2000) 3174-3179.

[11] J.L. Gomez-Eyles, M.T.O. Jonker, M.E. Hodson, C.D. Collins, Passive samplers provide a better prediction of PAH bioaccumulation in earthworms and plant roots than exhaustive, mild solvent, and cyclodextrin extractions, Environ. Sci. Technol. 646 (2011) 962-969.

[12] S. Li, T.A. Anderson, J.D. Maul, B. Shrestha, M.J. Green, J.E. Cañas-Carrell, Comparative studies of multi-walled carbon nanotubes (MWNTs) and octadecyl (C18) as sorbents in passive sampling devices for biomimetic uptake of polycyclic aromatic hydrocarbons (PAHs) from soils, Sci. Total Environ. 461462 (2013) 560-567. 
[13] S. Kohlmeier, M. Mancuso, U. Deepthike, R. Tecon, J.R. van der Meer, H. Harms, M. Wells, Comparison of naphthalene bioavailability determined by whole-cell biosensing and availability determined by extraction with Tenax, Environ. Pollut. 156 (2008) 803-808.

[14] N. Amellal, J.M. Portal, J. Berthelin, Effect of soil structure on the bioavailability of polycyclic aromatic hydrocarbons within aggregates of a contaminated soil, Appl. Geochem. 16 (2001) 16111619.

[15] N. Chung, M. Alexander, Differences in sequestration and bioavailability of organic compounds aged in dissimilar soils, Environ. Sci. Technol. 32 (1998)855-860.

[16] C. Cuypers, T. Grotenhuis, J. Joziasse, W. Rulkens, Rapid persulfate oxidation predicts PAH bioavailability in soils and sediments, Environ. Sci. Technol. 34 (2000) 2057-2063.

[17] E. Ferrarese, G. Andreottola, I.A. Oprea, Remediation of PAH-contaminated sediments by chemical oxidation, J. Hazard. Mater. 152 (2008) 128-139.

[18] A. Goi, M. Trapido, N. Kulik, Contaminated soil remediation with hydrogen peroxide oxidation, World Academy of Science, Eng. Technol. 3 (2009) 154-159.

[19] F. Laurent, A. Cébron, C. Schwartz, C. Leyval, Oxidation of a PAH polluted soil using modified Fenton reaction in unsaturated condition affects biological and physico-chemical properties, Chemosphere 86 (2012) 659-664.

[20] F.J. Rivas, Polycyclic aromatic hydrocarbons sorbed on soils: a short review of chemical oxidation based treatments, J. Hazard. Mater. 138 (2006) 234-251.

[21] M. Usman, P. Faure, K. Hanna, M. Abdelmoula, C. Ruby, Application of magnetite catalyzed chemical oxidation (Fenton-like and persulfate) for the remediation of oil hydrocarbon contamination, Fuel 96 (2012) 270-276. 
[22] M. Usman, P. Faure, C. Lorgeoux, C. Ruby, K. Hanna, Treatment of hydrocarbon contamination under flow through conditions by using magnetite catalyzed chemical oxidation, Environ Sci. Pollut. Res. 20 (2013) 22-30.

[23] M. Usman, P. Faure, C. Ruby, K. Hanna, Application of magnetite-activated persulfate oxidation for the degradation of PAHs in contaminated soils ,Chemosphere 87 (2012) 234-240.

[24] M. Usman, P. Faure, C. Ruby, K. Hanna, Remediation of PAH-contaminated soils by magnetite catalyzed Fenton-like oxidation, Appl. Catal. B 117-118(2012) 10-17.

[25] C. Valderrama, R. Alessandri, T. Aunola, J.L. Cortina, X. Gamisans, T. Tuhkanen, Oxidation by Fenton's reagent combined with biological treatment applied to a creosote-contaminated soil, J. Hazard. Mater. 166 (2009) 594-602.

[26] B.E. Huling, In-situ chemical oxidation, Engineering Issue, US-EPA, 2006, 58.

[27] R. Baciocchi, Principles, developments and design criteria of in situ chemical oxidation, Water Air Soil Pollut. 224 (2013) 1-11.

[28] S. Lundstedt, Y. Persson, L. Öberg, Transformation of PAHs during ethanol-Fenton treatment of an aged gasworks' soil, Chemosphere 65 (2006) 1288-1294.

[29] G.S. Brown, L.L. Barton, B.M. Thomson, Permanganate oxidation of sorbed polycyclic aromatic hydrocarbons, Waste Manage. 23 (2003) 737-740.

[30] L.T.C. Bonten, T.C. Grotenhuis, W.H. Rulkens, Enhancement of PAH biodegradation in soil by physicochemical pretreatment, Chemosphere 38 (1999) 3627-3636.

[31] M. Usman, Formation of mixed Fe"I-Fe $e^{\text {III }}$ oxides and their reactivity to catalyze chemical oxidation, in: Remediation of Hydrocarbon Contaminated Soils, Nancy Université, France, Nancy, 2011, pp. 225. 
[32] M. Usman, A. Chaudhary, C. Biache, P. Faure, K. Hanna, Thermal pretreatment as a novel way to increase availability of PAHs for their successive chemical oxidation in contaminated soils, Chemosphere, submitted.

[33] L. Jeanneau, P. Faure, Quantification of fossil organic matter in contaminated sediments from an industrial watershed: validation of the quantitative multimolecular approach by radiocarbon analysis, Sci. Total Environ. 408 (2010) 4251-4256.

[34] S.J. Rowland, R. Alexander, R.I. Kagi, D.M. Jones, A.G. Douglas, Microbial degradation of aromatic components of crude oils: a comparison of laboratory and field observations, Org. Geochem. 9 (1986) $153-161$.

[35] J.K. Volkman, R. Alexander, R.I. Kagi, S.J. Rowland, P.N. Sheppard, Biodegradation of aromatic hydrocarbons in crude oils from the barrow sub-basin of Western Australia, Org. Geochem. 6 (1984) $619-632$.

[36] J.A. Williams, M. Bjorøy, D.L. Dolcater, J.C. Winters, Biodegradation in South Texane Eocene oilseffects on aromatics and biomarkers, Org. Geochem. 10 (1986) 451-461.

[37] V. Flotron, C. Delteil, Y. Padellec, V. Camel, Removal of sorbed polycyclic aromatic hydrocarbons from soil, sludge and sediment samples using the Fenton's reagent process, Chemosphere 59 (2005) $1427-1437$.

[38] R.J. Watts, P.C. Stanton, J. Howsawkeng, A.L. Teel, Mineralization of a sorbed polycyclic aromatic hydrocarbon in two soils using catalyzed hydrogen peroxide, Water Res. 36 (2002) 4283-4292.

[39] C.L. Yap, S. Gan, H.K. Ng, Fenton based remediation of polycyclic aromatic hydrocarbonscontaminated soils, Chemosphere 83 (2011) 1414-1430.

[40] B.R. Petigara, N.V. Blough, A.C. Mignerey, Mechanisms of hydrogen peroxide decomposition in soils, Environ. Sci. Technol. 36 (2002) 639-645. 
[41] A. Cébron, P. Faure, C. Lorgeoux, S. Ouvrard, C. Leyval, Experimental increase in availability of a PAH complex organic contamination from an aged contaminated soil: consequences on biodegradation, Environ. Pollut. 177(2013) 98-105.

[42] S. Ouvrard, C. Barnier, P. Bauda, T. Beguiristain, C. Biache, M. Bonnard, C. Caupert, A. Cébron, J. Cortet, S. Cotelle, M. Dazy, P. Faure, J.F. Masfaraud, J. Nahmani, F. Palais, P. Poupin, N. Raoult, P. Vasseur, J.L. Morel, C. Leyval, In situ assessment of phytotechnologies for multicontaminated soil management, Int. J. Phytorem. 13 (2011) 245-263.

[43] A. Pernot, S. Ouvrard, P. Leglize, P. Faure, Protective role of fine silts for PAH in a former industrial soil, Environ. Pollut. 179 (2013) 81-87.

[44] S. Jonsson, Y. Persson, S. Frankki, B. van Bavel, S. Lundstedt, P. Haglund, M. Tysklind, Degradation of polycyclic aromatic hydrocarbons (PAHs) in contaminated soils by Fenton's reagent: a multivariate evaluation of the importance of soil characteristics and PAH properties, J. Hazard. Mater. 149 (2007) 86-96.

[45] G.L. Northcott, K.C. Jones, Partitioning, extractability, and formation of nonextractable PAH residues in soil. 1. Compound differences in aging and sequestration, Environ. Sci. Technol. 35 (2001) 1103-1110.

[46] S. Ouali, Bioremediation Trials of Polycyclylic Aromatic Compound Contaminated Soils (Essais De Traitabilité Par Voie Biologique Des Sols Contaminés Aux Composés Aromatiques Polycycliques), Microbiologie appliquée environnement santé Université Pierre et Marie Curie, Paris, 2013, pp. 39. [47] J. Lemaire, M. Buès, T. Kabeche, K. Hanna, M.-O. Simonnot, Oxidant selection to treat an aged PAH contaminated soil by in situ chemical oxidation, JECE 1(2013) 1261-1268.

[48] B.W. Bogan, V. Trbovic, Effect of sequestration on PAH degradability with Fenton's reagent: roles of total organic carbon, humin, and soil porosity, J. Hazard. Mater. 100 (2003) 285-300. 
[49] C. Kazunga, M.D. Aitken, A. Gold, R. Sangaiah, Fluoranthene-2,3- and -1,5-diones are novel products from the bacterial transformation of fluoranthene, Environ. Sci. Technol. 35 (2001) 917-922.

[50] H.H. Richnow, R. Seifert, J. Hefter, M. Kästner, B. Mahro, W. Michaelis, Metabolites of xenobiotica and mineral oil constituents linked to macromolecular organic matter in polluted environments, Org. Geochem. 22 (1994) 671-681.

[51] H. Weigand, K.U. Totsche, I. Kögel-Knabner, E. Annweiler, H.H. Richnow, W. Michaelis, Fate of anthracene in contaminated soil: transport and biochemical transformation under unsaturated flow conditions, Eur. J. Soil Sci. 53 (2002)71-81. 


\section{Supplementary Data}

Effect of pre-heating on the chemical oxidation efficiency: implications for the PAH availability measurement in contaminated soils

Coralie Biache $^{1,2}$, Catherine Lorgeoux ${ }^{3,4}$, Sitraka Andriatsihoarana ${ }^{1,2,3,4,5}$, Stéfan Colombano ${ }^{5}$, Pierre Faure $^{1,2}$

GC-MS analyses for PAH quantification S2

Table S1: PAH names and corresponding abbreviations used in the following Figures S3

Figure S1: PAH content for the references (one week in water) and samples treated with (a) $\mathrm{KMnO}_{4}$, (b) $\mathrm{H}_{2} \mathrm{O}_{2}$ and (c) Fenton-like (one week), with/without pre-heating ( $\pm \mathrm{SD}$; percentages correspond to the EOM decrease rate after the treatments compared to the reference counterparts) S4

Figure S2: 16 PAH concentrations in (a.) the coking plant, (b.) the gas plant and (c.) the wood-treating facility soils, for the references and the $\mathrm{KMnO}_{4}$ treated, unheated and pre-heated samples ( \pm STD). S5 Figure S3: 16 PAH concentrations in (a.) the coking plant, (b.) the gas plant and (c.) the wood-treating facility soils, for the references and the $\mathrm{H}_{2} \mathrm{O}_{2}$ treated, unheated and pre-heated samples ( \pm STD) .... S6 Figure S4: 16 PAH concentrations in (a.) the coking plant, (b.) the gas plant and (c.) the wood-treating facility soils, for the references and the Fenton-like treated, unheated and pre-heated samples $( \pm$ STD) S7 


\section{GC-MS analyses for PAH quantification}

Quantification of the 16 listed PAHs (Table S1) was carried out using internal calibration. An internal PAH standard mix of $\left[{ }^{2} \mathrm{H}_{8}\right]$ naphthalene, $\left[{ }^{2} \mathrm{H}_{10}\right]$ acenaphthene, $\left[{ }^{2} \mathrm{H}_{10}\right]$ phenanthrene, $\left[{ }^{2} \mathrm{H}_{12}\right]$ chrysene, $\left[{ }^{2} \mathrm{H}_{12}\right]$ perylene, supplied by Cluzeau ${ }^{\circledast}(20 \mu \mathrm{L}$ at $16 \mu \mathrm{g} / \mathrm{mL})$ was added to the EOM (80 $\mu \mathrm{L}$ ) before being injected in a gas chromatograph coupled with a mass spectrometer (GC-MS). For each quantified compound (Table S1), calibration curve was drawn with six concentrations $(0.3,0.9,1.5,3,6$ and 9 $\mu \mathrm{g} / \mathrm{mL}$ ). The gas chromatograph was a Shimadzu GC-2010 plus, equipped with a capillary column in silica glass DB-5MS (60 m $\times 0.25 \mathrm{~mm}$ i.d. $\times 0.1 \mu \mathrm{m}$ film thickness) coupled to a QP2010-Ultra (Shimadzu) MS in fullscan mode with a transfer line heated at $300^{\circ} \mathrm{C}$. The oven temperature program was as follow: $70^{\circ} \mathrm{C}$ for $2 \mathrm{~min}$, from 70 to $130^{\circ} \mathrm{C}$ at $15^{\circ} \mathrm{C} / \mathrm{min}$, then from 130 to $315^{\circ} \mathrm{C}$ at $3{ }^{\circ} \mathrm{C} / \mathrm{min}$ and then a $15 \mathrm{~min}$ hold at $315^{\circ} \mathrm{C}$. The carrier gas was helium at $1.4 \mathrm{~mL} / \mathrm{min}$ constant flow. 
Table S1: PAH names and corresponding abbreviations used in the following Figures

\begin{tabular}{ll}
\hline Name & Abbreviation \\
\hline Naphthalene & $\mathrm{Na}$ \\
Acenaphthylene & Acy \\
Acenaphthene & Ace \\
Fluorene & Fl \\
Phenanthrene & Phe \\
Anthracene & An \\
Fluoranthene & Fluo \\
Pyrene & Py \\
Benz[a]anthracene & BaA \\
Chrysene & Chry \\
Benzo[b]fluoranthene & BbF \\
Benzo[k]fluoranthene & BkF \\
Benz[a]pyrene & BaP \\
Indeno[1,2,3-cd]pyrene & IP \\
Benzo[ghi]perylene & BghiP \\
Dibenzo[a,h]anthracene & DBahA \\
\hline
\end{tabular}



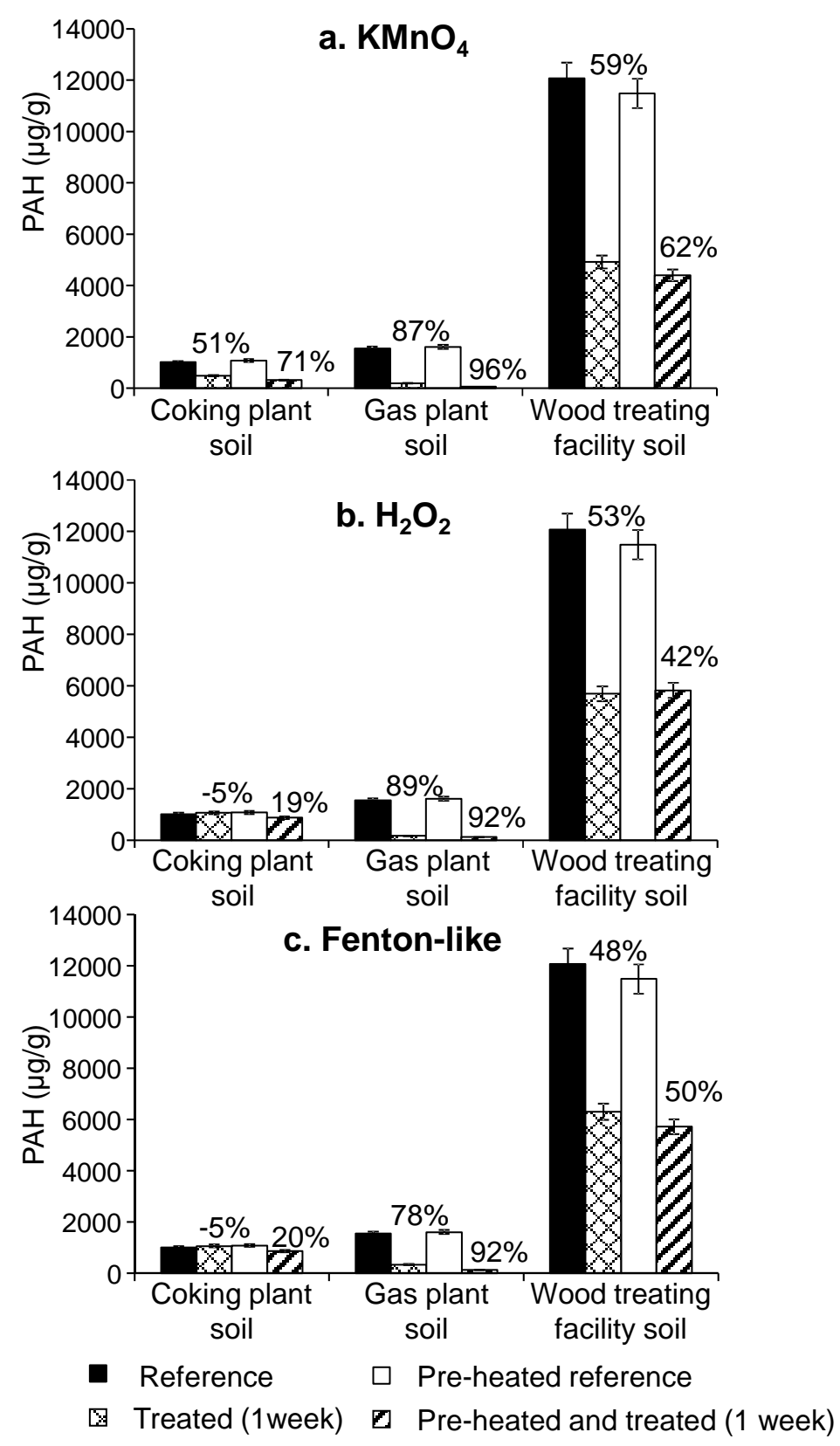

Figure S1: PAH content for the references (one week in water) and samples treated with (a) $\mathrm{KMnO}_{4}$, (b) $\mathrm{H}_{2} \mathrm{O}_{2}$ and (c) Fenton-like (one week), with/without pre-heating ( $\pm \mathrm{SD}$; percentages correspond to the EOM decrease rate after the treatments compared to the reference counterparts) 

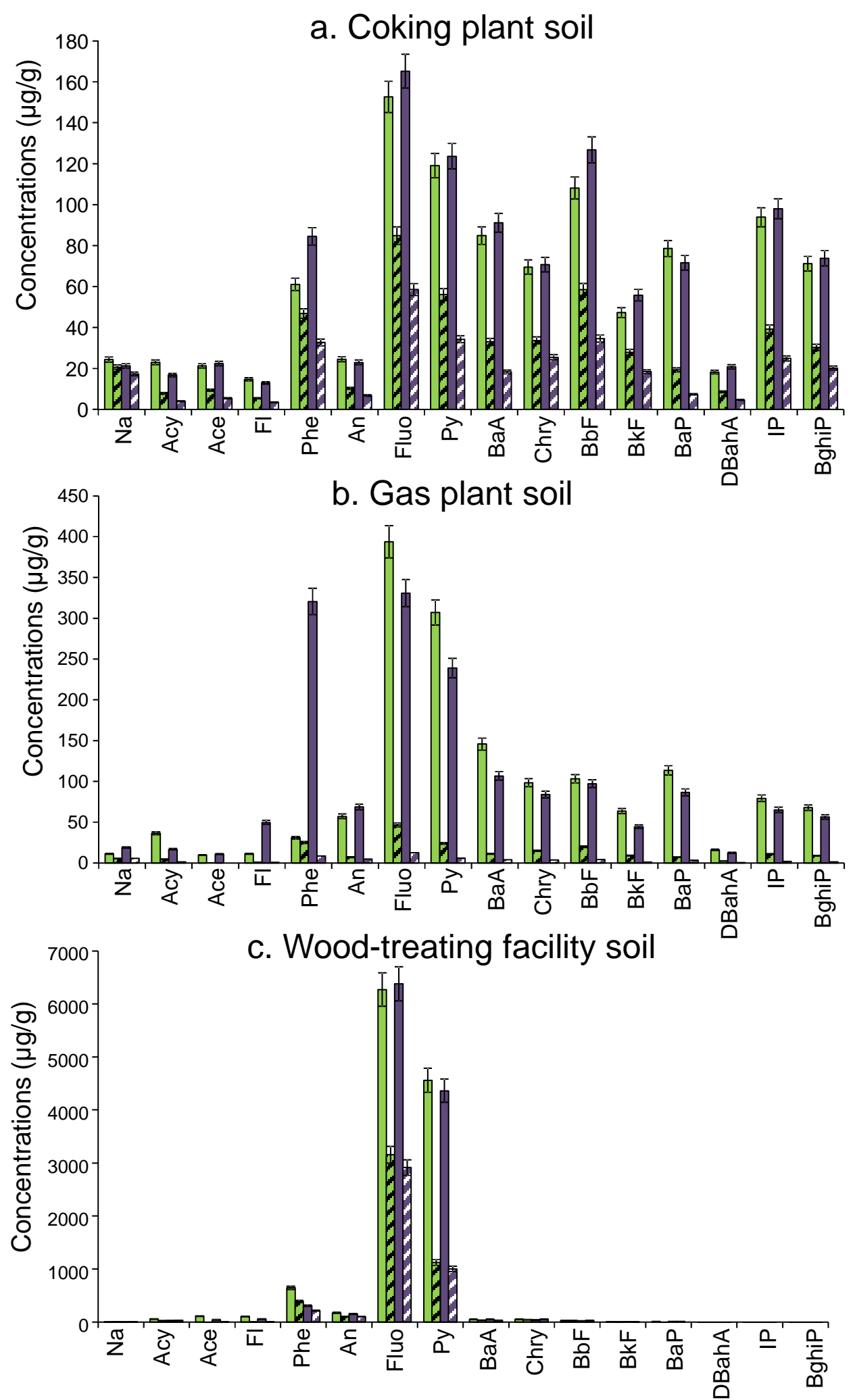

$\square$ Reference $\quad \square \mathrm{KMnO}_{4} \square$ Pre-heated reference $\square$ Pre-heated $\mathrm{KMnO} 4$

Figure S2: 16 PAH concentrations in (a.) the coking plant, (b.) the gas plant and (c.) the wood-treating facility soils, for the references and the $\mathrm{KMnO}_{4}$ treated, unheated and preheated samples ( \pm STD) 

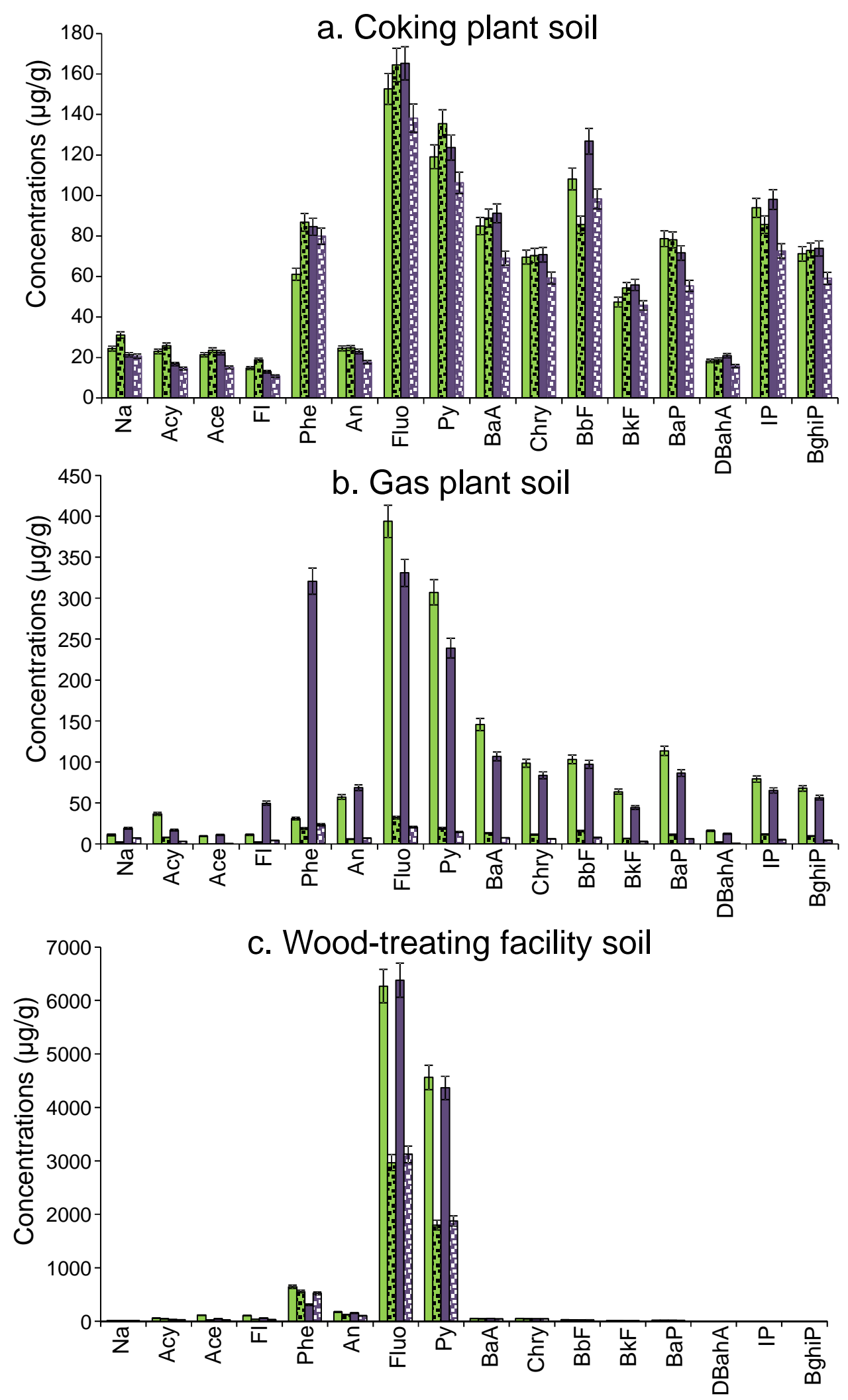

$\square$ Reference $\quad$ 图 $\mathrm{H}_{2} \mathrm{O}_{2} \quad \square$ Pre-heated reference 图 Pre-heated $\mathrm{H}_{2} \mathrm{O}_{2}$

Figure S3: 16 PAH concentrations in (a.) the coking plant, (b.) the gas plant and (c.) the wood-treating facility soils, for the references and the $\mathrm{H}_{2} \mathrm{O}_{2}$ treated, unheated and preheated samples ( \pm STD) 

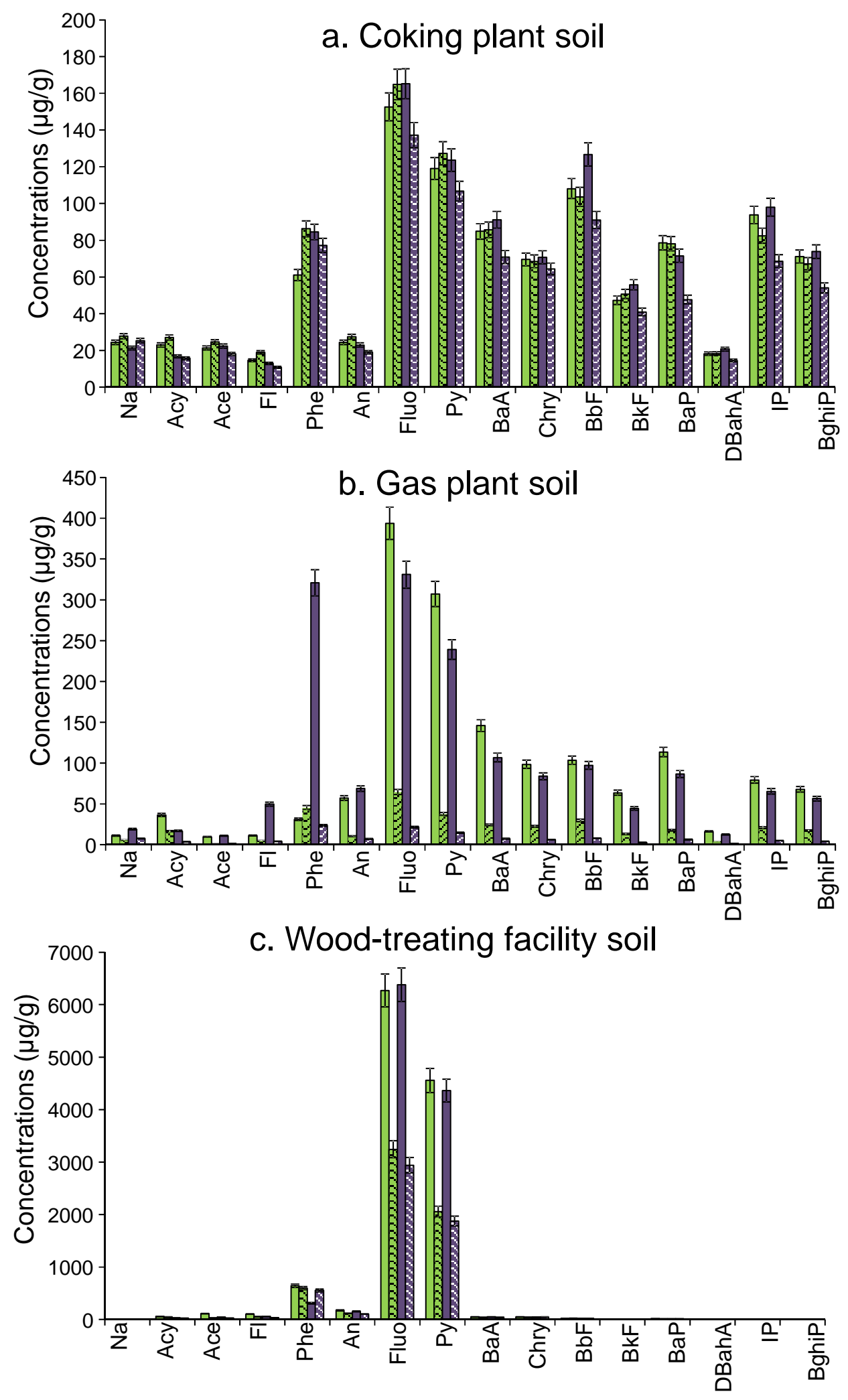

$\square$ Reference $\quad$ 秋 $\mathrm{KnO}_{4} \square$ Pre-heated reference $\square$ Pre-heated $\mathrm{KMnO}_{4}$

Figure S4: 16 PAH concentrations in (a.) the coking plant, (b.) the gas plant and (c.) the wood-treating facility soils, for the references and the Fenton-like treated, unheated and pre-heated samples ( \pm STD) 